\title{
Electoral Crime in Kosovo
}

\author{
Azem Hajdari \\ Faculty of Law, University of Prishtina "HasanPrishtina" \\ Pristina, Kosovo \\ E-mail: azemhajdari@outlook.com
}

Received: September 3, 2014 Accepted: September 29, 2014 Published: November 28, 2014

doi:10.5296/iss.v2i2.6698 URL: http://dx.doi.org/10.5296/iss.v2i2.6698

\begin{abstract}
Criminal offences against voting rights in Criminal Code of the Republic of Kosovo are listed in chapter XVIII. In this chapter the legislator has foreseen a total of eleven criminal offences. Through these criminal offences are protected free, legal and democratic elections. Criminal offences against voting rights directly affect in the quality of representative bodies, including the quality of governance, whether at central or local level. It has been a while that the Republic of Kosovo during electoral processes is facing a relatively high presence of these criminal offences. This fact is proven by numerous statistical data and reports of various international organizations. Modest results of this scientific paper prove that for commission of criminal offences against voting rights during the period of time 2009-2014 were filed 1619 criminal reports, were filed 583 indictments and were punished 206 persons (Note 1).

The consequences of these criminal offences are numerous and diverse, but mostly dominate those of political, economic and psychological nature etc. This situation highlights the need that regarding these criminal offences responsible state bodies (police, prosecution and courts) to undertake all the necessary legal measures to guarantee the successful fight against this type of criminality. In preparing this article I have used legaldogmatic, statistical, comparison and analysis methods.
\end{abstract}

Keywords: vote, voter, candidate, intimidation, abuse, forgery, annihilation 


\section{Introduction}

By criminal offences against voting rights are incriminated an entirety of criminal actions or omissions whereby is violated the electoral process legality. These criminal offences are in function of protecting free and democratic elections as well as the referendum legality. By Kosovo Criminal Code are foreseen a total of eleven criminal offences against voting rights. Within this paper will be discussed about the notion of criminal offences against voting rights, some of their manifestation forms and consequences they cause, their volume and dynamics. In this regard is intended to offer to the reader a general notion of these criminal offences, the most typical forms of their appearance, the numerous consequences they cause and a tabular overview regarding their presence degree in Kosovo during the period of time 2009-2014.

Consequently, within this article will also be discussed about some personal characteristics of criminal offences perpetrators against voting rights. As will be seen, the presence degree of criminal offences against voting rights manifests a relatively high presence, varied and disturbing for the country. Whereas in the end of this scientific paper will be discussed also about the measures to combat them, with special focus on repressive measures but without neglecting preventive measures.

\section{The Meaning (Notion) of Criminal Offences against Voting Rights}

In criminal legislation and legal literature until nowadays is not given any clear and full definition of the notion of criminal offences against voting rights. This is due to the fact these criminal offences in developed democracy states or are very few or completely absent and because of the fact that criminal law authors in scientific treatments of these criminal offences dealt a little. "A new and clearer definition of these criminal offences is recently made especially in criminal codes of countries which have started to face the cases of infringement, respectively the violation of voting rights, such is the case with Kosovo (Note 2)."

In this aspect, by criminal offences against voting rights is understood those illegal offences (actions and omissions) obstructing the implementation of constitutional and legal principles for free and democratic elections, committed intentionally and by a certain purpose (Note 3). Actions carried out in order to commit the se criminal offences consist in the use of force, threat, bribery, the abuse of economic and professional dependence and other unlawful actions. These are the actions that may affect in election's result (for political parties or candidates) and which endanger the democratic election system.

\section{Some Manifestation Forms of Criminal Offences against Voting Rights}

Manifestation forms of criminal offences against voting rights are numerous and diverse. They consist in obstructing unlawfully to exercise the voting right of another person (for instance does not register such person in voters registration list); using of violence, threat, giving bribes, the abuse of economic and professional dependence of the voter etc. in order to vote in a certain manner or not vote at all in elections; vote on behalf of another 
person, disclosing the confidentiality of voter's voting; falsification of election results; damage and destruction of election documents etc. (Note 4).

Modest results of this paper prove that in Kosovo, almost in all elections held after 1999 onward, were manifested all abovementioned forms of voter's vote manipulation. This vote manipulation, however had achieved the highest presence levels during local elections in 2009 and central elections in 2010, when is marked the biggest number of persons against whom were filed 1490 criminal reports, were filed 519 indictments and were punished (190). These elections were characterized by the phenomenon of so-called "industrial theft" of vote. In this regard it is considered that the political party who had the power in that time (PDK), but without excluding other political parties through their commissioners realized the scenario of filling voting boxes by completed ballots by those commissioners, realized the scenario of changing voting boxes during the process of their transfer at Counting Center Results in Fushë Kosovë and purchase of votes all over the country. Consequently, during these elections, but also later held elections (2013 and 2014), although in multiple smaller dimensions due to the huge international pressure, electoral processes were characterized by family voting phenomenon, voting on behalf of another person (alive or dead, Note 5), voting more than once of a voter etc.

During these elections vote manipulation phenomenon (purchase, theft etc.) were manifested in terms of vote robbery by another political party, but especially in terms of vote displacement from one candidate to another within competing political party in elections. The result of these manipulations were the selection in key positions of local power (mayors) and central power (deputies, ministers etc.) of not less persons unable to cope with the challenges faced by the position in which they were elected.

Finally, based on Kosovo Judicial Council data and Basic Courts judgments will be presented the data concerning the number of convicted persons for commission of criminal offences against voting rights during the period of time 2009-2014. According to these data courts have imposed punishments against 87 persons for commission criminal offences of the abuse of official position or authority, 43 persons for falsification of voting results, 32 persons for violation of voting confidentiality, 21 persons for violation of free determination of voters and 23 persons for other criminal offences against voting rights. These numbers attest for manifestation of different forms of commission criminal offences against voting rights in Kosovo during the period of time 2009-2014.

\section{Some of the Consequences of Criminal Offences against Voting Rights}

Criminal offences against voting rights cause a numerous and varied consequences. The consequences caused by these criminal offences, generally may be of political, psychological and economic nature etc.

Modern reality of life proves that through commission of criminal offences against voting rights is affected efficiently in political life course. This due to the fact that through commission of these criminal offences is affected directly in governance quality, based on the fact they determine the political force and persons within it that will govern the country. In fact, persons who come to power through vote manipulation usually do not feel 


\section{Macrothink $\Lambda$ Institute ${ }^{m+}$}

the responsibility about the way how they will govern their country or municipality. Already is worldwide known that "a high level presence of these criminal offences obstructs political and institutional reforms, it causes obstacles and difficulties related to integration of country in international organizations and institutions, antipathy towards such state "problematic" etc. Such consequences already felt Kosovo citizens. In fact, criminal offences against voting rights, especially when in their commission are involved persons who exercise high public functions, cause also the loss of citizens hope concerning their country perspective (Note 6).

Except the political consequences the criminal offences against voting rights cause also psychological consequences. The fact that commission of these criminal offences is encouraged and stimulated from influence persons at institutional and political life, they have never been through a prosecution or trial process for them, as well as the fact that even when their perpetrators are prosecuted and tried minimum punishments are imposed to them, it affects to one part of public opinion to be created the impression that this criminality is unbeatable. Symbolic cases of prosecutions and trials related to persons for commission of criminal offences against voting rights concerning local elections in 2009 and central ones in 2010 where there was a flagrant abuse of citizens vote (Note 7) and the punishment of only 206 persons, and ignoring persons who incite them (candidates for deputy and mayors, political persons etc.) are factors who exercise direct psychological effect in different categories and groups of citizens. This affects in the low degree participation of citizens in elections and other political processes, and to that extent that some individuals may be stimulated to practice the same thing in order to get or change the power in favor of a certain political party.

Criminal offences against voting rights reflect also economic influences. These criminal offences, being associated with many different interests, in one way or another attack the businesses, because in many cases their perpetrators seek to them financial support during electoral campaigns, obstruct the international and national potential investments, because usually political composition getting the governance through manipulated elections represents a composition led to corruption, the damage of state budget etc. based on the fact that in every case of change local or central power, powers acquired and internal audits conducted have brought to light large abuse of public money (Note 8).

For the high degree manipulations of electoral processes in Kosovo and their consequences to the country warned also different international organizations reports, but also civil society of the country. They all have pointed out the need for reforming electoral system and change the approach against the manner of getting and holding the power, in order to open development and integration prospects. Unfortunately these requirements in the political calculations remain without any substantial result, despite the fact that international pressure exerted its influence in reducing the level of commission of criminal offences against voting rights during the local elections in 2013 and those central in 2014.

Faced with this situation it is a legal duty of main institutional factors to undertake any measure allowed by the law and thus to take the responsibility they belong for combating 


\section{Macrothink}

crime of any kind, including electoral crime, in order to return to country the perspective once and for all.

\section{Volume, Dynamics and Territorial Scope of Criminal Offences against Voting Rights}

Volume, dynamics and territorial scope of criminality in general, respectively a certain type of criminal offences represent criminological categories through which is aimed to present the level and movement of corresponding criminal phenomenon during years and particular regions of a country and wider. In attempting to achieve this goal, in the following of this paper will be discussed about these categories, of course related to the criminal offences against voting rights in Kosovo.

\subsection{The Volume}

The volume treatment of criminal offences against voting rights as its own goal has the presentation of their presence level in the country. Of course, the real presence presentation related to this type of criminal offences, similar as other forms of criminality, is a complex as well as challenging and unsolvable problem. "This happens due to the fact that accurate volume of criminality appeared in society, regardless of formal identification, almost is not known, because it is never fully identified, is not known entirely, due to the different circumstances prevailing in society" (Note 9). Considering the fact that also to these criminal offences are presented these circumstances, and then also the statistical data which we refer concerning their volume, must be seen from this point of view with all reservations, which are usually present at researches of this type.

Regardless of this, for purposes of this research, in the following diagram will be presented the data concerning the number of criminal reports filed for commission of criminal offences against voting rights (Note 10), and the number of convicted persons concerning these criminal offences during the period of time 2009-2014.

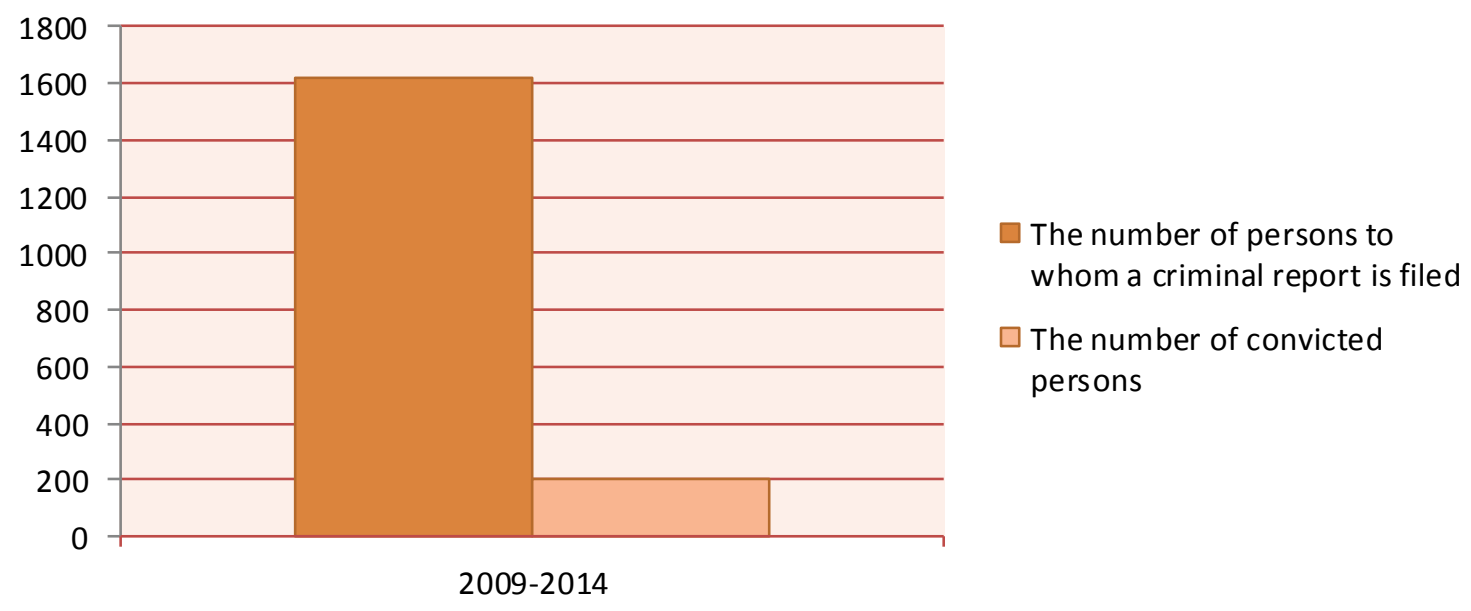

Figure 1. Volume electoral crime 


\section{Macrothink}

According to these data (Note 11) during the period of time 2009-2014 in Kosovo for commission of criminal offences against voting rights were punished 206 persons. This number of convicted persons seems symbolic in comparison to the number of 1619 persons to whom were filed criminal reports, and especially the perception level of public opinion that exists regarding the high degree of vote manipulation during the local elections in 2009 and the central ones in 2010.

\subsection{The Dynamics}

Also, in the context of manifestation over years, will be reflected the presence level of criminal offences against voting rights in Kosovo during the years 2009-2014. A support point of this reflection will be the convicted number of persons for commission of these criminal offences. In fact, in the following diagram will be presented Kosovo Judicial Council and Basic Courts data over the number of convicted persons for commission of these criminal offences according to elections chronological course held during the period 2009-2014.

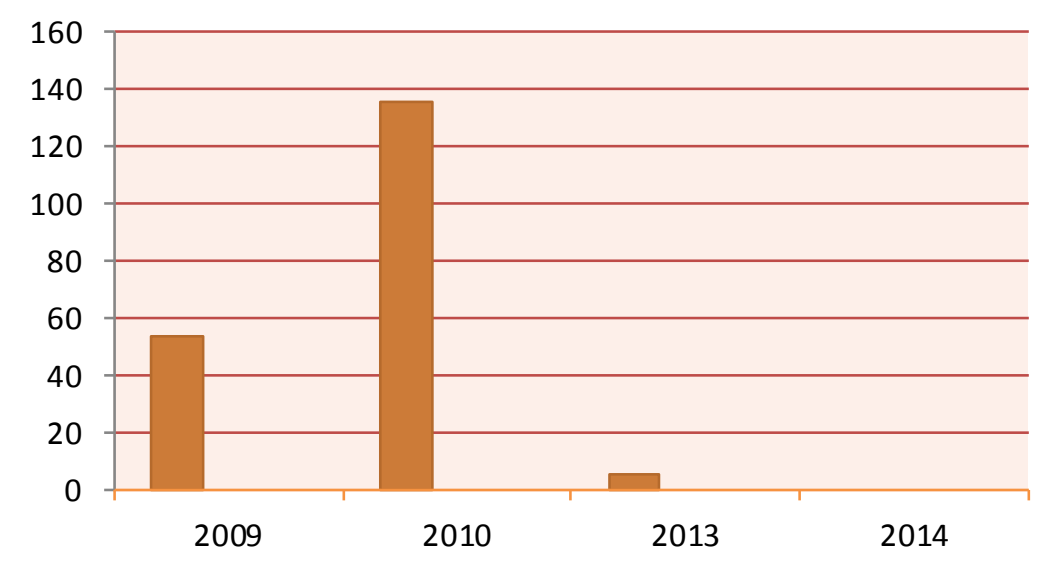

The number of convicted persons

Figure 2. Dynamics of electoral crime

According to these data (Note 12) the biggest number of persons (190 perpetrators) for commission of criminal offences against voting rights were punished related to committed criminal acts during local elections in 2009 and central elections in 2010. These data indicate that for local elections in 2009 were punished 54 persons, for central elections in 2010 a total of 136 persons, for local elections of 2013 were punished 16 persons, whereas for central elections in 2014 (probably for procedural reasons) not a single person has been punished. The highest number of criminal offences against voting rights committed during the local elections in 2009 and the central ones in 2010 must be linked by all means with the lack of experience regarding the elections characterized the responsible bodies of the country for organization of elections after Kosovo's declaration of independence, but also with the ambitions expressed by political forces to take over power benefits and the merits of country statehood. In meanwhile, multiple smaller number of convicted persons for local elections held in 2013 and central elections in 2014 it may be explained by a huge international pressure regarding these elections and a high level of commitment by police 
and prosecution state so in these elections to fulfil the mission specified by the law in order to ensure the punishment of crime and guarantee free and democratic elections.

\subsection{Territorial Scope}

Through territorial scope as criminological component is intended to reflect the data regarding the presence level of criminal offences against voting rights through Kosovo respective regions. Also within this treatment will be used Kosovo Judicial Council data and Basic Courts judgments regarding the number of convicted persons for commission of these criminal offences. Consequently, in the following table will be presented the data concerning the number of convicted persons for commission of these criminal offences in six Kosovo regions during the period of time 2009-2014.

Table 1. Territorial scope of electoral crime

\begin{tabular}{lc}
\hline Regions & The numberofconvictedpersons \\
\hline Prishtina & 97 \\
Gjilan & 14 \\
Ferizaj & 23 \\
Gjakova & 09 \\
Mitrovica & 12 \\
Prizren & 21 \\
Peja & 24 \\
In total & 209 \\
\hline
\end{tabular}

According to these data (Note 13), the biggest number of convicted persons for commission of criminal offences against voting rights comes from Prishtina region. Such are 97 persons, and then comes Peja with 24, Ferizaj with 23, Prizren with 21 and so on. The cause of such high participation of perpetrators from Pristina region in commis sion of these criminal offences against voting rights must be linked by all means with the ambitions that political parties have in order to expand the influence degree in the capital, but also due to the fact of demographic and cultural movements accompanied this region in the postwar period.

\section{Some of the Perpetrators Personal Data}

Criminality in general, therefore also some types of criminality in particular, they cannot be explained entirely in their complexity without being studied and solved also some personal and social data of these behaviours, because criminality as a general phenomenon is manifested through concrete commission of criminal offences (Note 14). Having in mind this fact, in the following will be discussed about the age, gender, educational level and social affiliation of criminal offences perpetrators against voting rights. 
6.1 The Perpetrator's Age

Age is an important characteristic of the criminal phenomenon that it has a special weight in explaining criminal behaviors (Note 15). Numerous statistical data from judicial practice, as well as criminological researches data prove that perpetrators belong to different age persons. This fact is present in all criminal offences, and thus also in criminal offences against voting rights. The results of this scientific paper prove that the perpetrators of these criminal offences mainly are adults. In the following table will be presented the age of convicted persons for commission of criminal offences against voting rights during the period of time 2009-2014.

Table 2. The perpetrator's age of electoral crime

\begin{tabular}{lc}
\hline The age ofconvictedpersons & The number \\
\hline $14-18$ & 3 \\
$18-28$ & 89 \\
$28-38$ & 66 \\
$38-48$ & 37 \\
$48-58$ & 11 \\
58 e tutje & 00 \\
& 206 \\
\hline
\end{tabular}

According to these data (Note 16) the criminal offences against voting rights usually were committed by persons of ages between 18-28 years, in 89 cases, and then come the persons who belong ages between 28-38 years with 66 cases, the persons of ages 38-48 with 37 cases and so on. The commission of the biggest number of criminal offences against voting rights by persons of mentioned ages it is explained by the fact that persons of these ages are mostly engaged in official duties during elections, that is why this group of persons have come to a situation that more often to commit these criminal offences.

\subsection{The Perpetrator's Gender}

Also the gender, similar as the age presents an important characteristic of criminal phenomenon, that has a certain importance in explaining criminal behaviors. Exists a general impression that criminality is a typical phenomenon of masculine gender (Note 17). Numerous researches conducted for different forms of crimes in many world countries prove this fact. This tendency is noticed also in commission of criminal offences against voting rights. The data regarding convicted persons for commission of these criminal offences prove that as subject of these criminal offences appear mainly males. In the following table will be reflected the gender of convicted persons for commission of criminal offences against voting rights during the period of time 2009-2014. 
Table 3. The perpetrator's gender of electoral crime

\begin{tabular}{lc}
\hline The gender of convicted persons & The number of convicted persons \\
\hline Male & 203 \\
Female & 3 \\
In total & 206 \\
\hline
\end{tabular}

Such high participation of males in commission of criminal offences against voting rights must be explained by the fact that were males who over $95 \%$ of cases were engaged as commissioners of voting centers (Note 17). Consequently, the fact of such participation of women in commission of these criminal offences is linked with the still insufficient engagement of women in commissioner's positions and other official positions related to elections.

\subsection{The Perpetrator's Educational Level}

Numerous criminological researches consider education as an important factor in prevention of crime. This fact is proven also in modest results of this scientific paper. What is the participation degree of convicted persons in commission criminal offences against voting rights during the period of time 2009-2014 based on the perpetrator's educational level is best proved from the data that will be reflected in the following table.

Table 4. The perpetrator's educational level of electoral crime

\begin{tabular}{lc}
\hline Educational level of convicted persons & The number \\
\hline Without a complete primary eduation & 13 \\
With primary education & 39 \\
With secondary education & 154 \\
With faculty & 00 \\
In total & 206 \\
\hline
\end{tabular}

According to these data (Note 18) the biggest number of convicted persons for commission of criminal offences against voting rights belongs to the persons with secondary education. These persons participate in commission of these criminal offences with 154 cases, and then come persons with primary education with 39 cases and persons without primary education (only with some elementary classes completed) with 13 cases. The highest degree participation of persons with completed secondary education in commission of criminal offences against voting rights also should be seen in their level of dedication as commissioners in voting centers, but without excluding other influential factors, as may be those linked with the manipulation of these persons which usually are persons who see themselves lost in the labour and knowledge market.

\subsection{The Perpetrator's Social Background}

Numerous data from judicial practice and the researches from criminological studies attest that the biggest number of perpetrators regarding criminal offences against voting rights 
derives from unemployed people and with difficult material situation. This fact has been proven also by modest results of this paper.In the following table will be presented the data over social affiliation of convicted persons for commission of these criminal offences during the period of time 2009-2014.

Table 5. The perpetrator's social background of electoral crime

\begin{tabular}{lc}
\hline Social affiliation of convicted persons & The number of convicted persons \\
\hline Employed & 33 \\
Unemployed & 173 \\
In total & 206 \\
\hline
\end{tabular}

According to these data (Note 19) from 206 convicted persons 173 of them were unemployed. Commission of such high number of criminal offences against voting rights by unemployed people it is explained by difficult economic situation of the country and with the absent of citizens perspective regarding their employment. It is considered that the majority of these persons were included in commission of these criminal offences based on the public or individual promises made for their employment after winning the elections by influential persons in public life of the country. Based on this fact it may be concluded that with the growth of employment and citizens welfare the commission of these criminal offences will be reduced.

\section{The Measures for Combating Criminal Offences against Voting Rights}

For preventing and combating of criminal offences against voting rights as well as the criminality in general during the historical development of human society were used different tools and methods. All the measures used for combating of criminal offences against voting rights may be divided into: preventive and repressive measures.

\subsection{Preventive Measures}

By the word preventive measures is understood the entirety of actions undertaken by a wide circle of state entities in order to prevent criminality appearance as sociopathological phenomenon, through eliminating and combating of causes and conditions who determine it (Note 20). Preventive measures undertaken in order to prevent the commission of criminal offences against voting rights may be numerous and varied. Such measures may be of general and concrete nature.

Measures of general nature have to deal with the advancement of social position and population welfare, the increase of educational and cultural level, the balance and stabilization of social and political circumstances, the change of social environment and its humanism, strengthening democracy and rule of law etc (Note 21).

Whereas by measures of special nature is understood the measures undertaken by judicial bodies and other social and state entities of certain community. These measures concerning criminal offences against voting rights should be focused in: 
- Issuing of respective legislation;

- Establishing the responsible and effective mechanisms in order to fight criminal offences against voting rights;

- Efficient exercise of responsibilities by the police, state prosecution and courts with the purpose of detecting, prosecuting, arresting and punishing perpetrators of these criminal offences;

- Better work organization on security issues and the re-socialization of prisoners in penitentiary institutions, in order to avoid recidivism cases.

- The advancement of international cooperation level between Kosovo police, state prosecution and courts with other states and specialized institutions for combating crime (Interpol and Europol);

- The realization of deep reforms in electoral system. It is meant in issuing a legislation that would close the paths of vote manipulation;

- $\quad$ Cleaning up the voting lists;

- Entering of new voting methods, as it can be the electronic voting etc.

It is evident that implementation of these measures and other measures of this nature in Kosovo did not have a good performance during these transition years. In this regard, is estimated that undertaking such measures is the best guarantee of long-term fighting criminal offences against voting rights.

\subsection{Repressive Measures}

Repression is another form of social reaction against criminality. That job is entrusted mainly to bodies and specialized organizations, in the first place of those state (police, prosecution, courts execution sentences bodies etc.). Repressive measures are foreseen by the law and as such intended to protect life and other human values and society from criminal acts (Note 22). Repressive measures used for fighting of criminal offences against voting rights may be of two types: the detecting and prosecuting policy of criminal offences perpetrators against voting rights and application policy of criminal sanctions against their perpetrators.

7.2.1 The Detecting and Prosecuting Policy of Criminal Offences Perpetrators against Voting Rights

The detecting and solving of criminal offences against voting rights and their perpetrators it has a special importance in combating this form of criminality. The detection of these offences is very important also in reducing their dark figure of crime. It is considered that until now in Kosovo is not done enough in combating of criminal offences against voting rights. The reasons for this are numerous and varied. "They first of all have to do with the detection of commission circumstances of these criminal offences, of their perpetrators (Note 23), but mostly with inadequate treatment done by competent bodies to criminal offences against voting rights (negligence in combating, Note 24). 
Except the detection and identification of criminal offences against voting rights the key issue in order for justice to triumph against crime is the detection and bringing to justice their perpetrators. The results of this paper prove that in this regard, despite the achieved results, in police and prosecution job are manifested certain stagnations. These stagnations are manifested mostly in investigation of senior public officials when they are included in commission of these criminal offences. "Thus, according to Kosovo Police data for the period of time 2009-2014 were filed 1619 criminal reports concerning the criminal offences against voting rights (Note 25). Among these investigations is not even a single case involved any Kosovo senior and state political officer, despite the fact that a number of them have encouraged and stimulated their commission.

After the detection of criminal offences perpetrators against voting rights, in order for the fight against this form of crime to achieve the desirable effects is necessary that they must be prosecuted and arrested. The results of this paper prove that during the period of time 2009-2014 for criminal offences against voting rights were arrested 437 persons, of whom 377 were released after deadline expiration of 48 hours of their arrest (Note 26). Also, according to State Prosecution data for commission of criminal offences against voting rights during the conducting period of this research were filed 583 indictments (Note 27).

In order to achieve a more successful fight of criminal offences against voting rights is required an advanced engagement of authorized bodies for combating crime (police, state prosecution, courts etc.) de-politicization in the work of these bodies, cooperation and professional teamwork which in matters regarding the fight of this form of crime are more than necessary.

7.2.2 Application Policy of Criminal Sanctions Regarding Criminal Offences Perpetrators against Voting Rights

Successfully combating of criminal offences against voting rights can contribute significantly, by applying adequate criminal policy in the field of criminal sanctions application. "In this regard, the main role belongs to punishments imposed against criminal offences perpetrators during criminal proceedings" (Note 28). In this case, is deemed in adequate punishments, such that are in accordance with social dangerousness degree of criminal offence and its perpetrator.

The modest results of this paper prove that during the period of time 2009-2014 courts imposed punishments by imprisonment to 113 persons, which were punished by an average of 7 months and 15 days of imprisonment, punishment by fine to 34 persons, suspended sentence to 52 persons, and other punishments to 7 persons. It is worth it to emphasize the fact during this period of time has come to the statutory limitation of 58 cases for which indictment has been filed (Note 29).

These data prove that Kosovo courts concerning perpetrators of criminal offences against voting rights have applied relatively soft criminal policy and in their work is noticed considerable work negligence. Bearing in mind the relatively high presence degree of criminal offences against voting rights in Kosovo, especially the major consequences this form of criminality is causing to the country especially in political, economic and 
integrating aspect I consider that courts is supposed to aggravate to the maximum criminal policies as well as give priority to the electoral cases, not only in declarative terms but a lso in practical one.

\section{Conclusion}

The results of this paper have led me to these main conclusions:

By criminal offences against voting rights is understood those unlawful offences (actions or omissions) obstructing the implementation of constitutional and legal principles for democratic and free elections, committed intentionally and with a certain purpose. Actions carried out in order to commit these criminal offences consist in the use of force, coercion, bribery, the abuse of economic and professional dependence and other illegal actions. These are the actions that may affect in the election results (for political parties or candidates) and which put in danger the democratic electoral system.

According to Kosovo Judicial Council data during the period of time 2009-2014 in Kosovo for commission of criminal offences against voting rights were punished 206 persons. This number of punished persons seems symbolic in comparison to the number of 1619 persons against whom were filed criminal reports, and especially the perception level of public opinion that exists a high degree of vote manipulation during the local elections in 2009 and central elections in 2010.

According to Kosovo Judicial Council data the criminal offences against voting rights during the period of time 2009-2014 have been expanded in the whole Kosovo territory. Despite this, the data for convicted persons (206) prove that the biggest number of convicted persons for commission of these criminal offences comes from Pristina Region with 97 persons, and then it comes Peja with 24, Ferizaj with 23, Prizren with 21 and so on. The cause of the highest participation of Pristina region in commission criminal offences against voting rights must be linked by all means with the ambitions that political parties have in order to expand the influence degree in the capital, but also due to the fact of demographic and cultural movements accompanied this region in the postwar period.

Criminal offences against voting rights cause numerous consequences. They damage the state image in international aspect, damage the way of state functioning as well as the economic development of the country.

In prevention of criminal offences against voting rights a special importance has the democracy consolidation and rule of law as well as the de-politicization of state authorities (police, prosecution and courts). In order for this to happen is necessary that these authorities to increase their work efficiency in combating crime.

In combating and preventing of criminal offences against voting rights the role of criminal legislation is very important, because by incrimination of dangerous behaviours, is affected preventively to citizens to refrain from commission criminal offences and support the necessity to be more efficient and applicable, in order to provide wide acting opportunities to criminal justice bodies. 
In combating criminal offences against voting rights the special importance has adequate punitive policy. This policy in Kosovo is estimated to be soft and insufficient in order to fight effectively this form of criminality. Therefore, I consider that an aggravation of punitive policy may be an important contribution in reducing criminal offences against voting rights.

\section{References}

Ačimović, M. (1976). Pravci kriminal nepsihologije. Beograd.

Elezi, I. (2010). Criminal Law, The Special Part.Tirana.

Hajdari, A. (2002). War crimes against civilian population in Kosovo during the period February 1998-June 1999. Prishtina.

Hajdari, A. (2003). Corruption criminal offences with a special focus in Kosovo. Prishtina.

Halili, R. (1987). Criminality against marriage and family in Socialist Autonomous Province of Kosovo. Prishtina.

Halili, R. (2000). Criminology. Prishtina.

Kosovo Police statistical reports regarding criminal reports filed for the period of time 2009-2014.

Milutinoviq, M. (1987). Criminal policy. Prishtina.

Salihu, I, Zhitija H., \& Hasani F. (2014). Criminal Code of the Republic of Kosovo, Commentary (p. 573). Prishtina.

Salihu, I. (2014). Criminal Law, The Special part (p. 436). Pristina.

Statistical reports (periodical and annual) of Kosovo Judicial Council over the manner of resolving court cases for the period of time 2009-2014.

\section{Notes}

Note 1 . In this research were included 4 pairs of elections held in Kosovo, two pairs of national level and two pairs of local.

Note 2. Ismet Salihu, Criminal Law, The Special Part, Pristina, 2014, p. 436.

Note 3. Hilmi Zhitija, Ismet Salihu, and Fejzullah Hasani, Criminal Code of the Republic of Kosovo, Commentary, Pristina, 2014. p. 573.

Note 4. Ismet Elezi, Criminal Law, The Special Part, Tirana, 2010, p. 457.

Note 5. In Kosovo even 15 years after the war (1999) in the voter's lists are hundredsthousands dead persons, missing and those who renounced from citizenship.

Note 6. Ibid. p. 57. 
Note 7. During these elections happened a numerous industrial theft of vote as: filling voting boxes, voting on behalf of dead persons who did not participate in elections etc damaging certain political parties, as well as the major displacement of votes within political parties itself, that damaged significantly candidates for deputy that had no political strength for preserving their vote.

Note 8 . In all these cases were reported big expenses of financial means from the line of goods and services expenditures, which are related to nutrition and official trips, by not leaving aside also the change of capital expenditures destination.

Note 9. Compare: Ragip, Halili, Criminality against marriage and family in Socialist Autonomous Province of Kosovo, Pristina, 1987, p. 84.

Note 10. See: Statistical report of Kosovo Police regarding criminal reports filed for the years 2009-2014.

Note 11. The source of data from diagram 1: Kosovo Judicial Council statistical reports (periodical and annual) over the manner of resolving court cases and Basic Courts judgments for the period of time 2009-2014.

Note 12. The source of data from diagram 2: Kosovo Judicial Council statistical reports (periodical and annual) over the manner of resolving court cases and Basic Courts judgments for the period of time 2009-2014.

Note 13. The source of data from the table 1: Kosovo Judicial Council statistical reports (periodical and annual) over the manner of resolving court cases and Basic Courts judgments for the period of time 2009-2014.

Note 14. Mihajlo Ačimović, Pravci kriminalne nepsihologije, Beograd, 1976, pp. 7-8.

Note 15. Ragip,Halili, Criminology, Pristina, 2000, p.76.

Note 16. The source of data from the table 2: Kosovo Judicial Council statistical reports (periodical and annual) over the manner of resolving court cases and Basic Courts judgments for the period of time 2009-2014.

Note 17. Ragip,Halili, Criminology,...,p. 77.

Note 18. The source of data from the table 3: Kosovo Judicial Council statistical reports (periodical and annual) over the manner of resolving court cases and Basic Courts judgments for the period of time 2009-2014.

Note 19. Ibid.

Note 20. Ibid.

Note 21. Milan, Milutinoviq, Criminal policy, Pristina, 1987, p. 388.

Note 22. Ibid. p. 381.

Note 23. Compare: Azem, Hajdari, Corruption criminal offences with a special focus in Kosovo, Pristina, 2003, p. 124-125. 
Note 24. Compare: Azem Hajdari, War crimes against civilian population in Kosovo during the period February 1998-June 1999,,Prishtina, 2002, p. 252.

Note 25. Azem, Hajdari, Corruption criminal offences,...,p. 127.

Note 26. According to the research conducted by KIPRED concerning prosecutions and trials of election crimes in Kosovo only regarding central elections in 2010 were filed 1217 criminal reports.

Note 27. See: Police statistical data over criminal reports filed during the years 2008-2013.

Note 28. See: State prosecution statistical data over indictments filed during the years 2009-2014. Milan ,Milutinoviq, Criminal policy,..., p. 258.

Note 29. See: Statistical reports (periodic and annual) of Kosovo Judicial Council over the manner of resolving court cases for the period of time 2009-2014. 